\title{
The role of submucosal oedema in increased peripheral airway resistance by intravenous volume loading in dogs
}

\author{
G-J. Tang*, A.N. Freed**
}

The role of submucosal oedema in increased peripheral airway resistance by intravenous volume loading in dogs. G-J. Tang, A.N. Freed. CERS Journals Ltd 1994.

ABSTRACT: Pulmonary congestion leads to an increase in airway resistance. It is still unknown whether this is due to vascular engorgement or to submucosal oedema. The present study was designed to determine the relative contribution of these two potential mechanisms.

We examined the effect of intravenous volume loading on canine peripheral airway resistance $(\mathrm{Rp})$. Bronchoscopes were wedged in contralateral sublobar segments and used to record $\mathrm{Rp}$ during rapid infusion of normal saline.

Volume loading with normal saline increased pulmonary capillary wedge pressure (PCWP) and Rp. Unlike normal saline, dextran 70 did not increase Rp when infused at a rate that produced similar changes in PCWP. During infusion of normal saline, $\Delta \mathbf{R p}$ was significantly enhanced in lung segments previously challenged with dry air when compared to contralateral control lungs, unexposed to dry air, and the use of dextran 70 significantly reduced this effect. Vasoconstriction with phenylephrine significantly decreased baseline $\mathrm{Rp}$, but did not completely reverse the effect of fluid infusion. In addition, in lung segments exposed to dry air, $\Delta \mathbf{R p}$ was significantly greater after volume loading and treatment with phenylephrine when compared to contralateral control lung. Finally, muscarinic receptor blockade was ineffective in preventing $\mathrm{Rp}$ from increasing during infusion of normal saline.

Our results suggest that volume loading-induced increases in $\mathbf{R p}$ are not caused by either vascular engorgement or the stimulation of muscarinic receptors. Our data are consistent with the hypothesis that submucosal oedema formation is the mechanism responsible for normal saline infusion-induced increases in peripheral airway resistance.

Eur Respir J., 1994, 7, 311-317.

\begin{abstract}
*Dept of Anesthesiology, Taipei Veterans General Hospital, National Yang-Ming Medical College Taipei, Taiwan, Republic of China. **Dept of Environmental Health Sciences, The Johns Hopkins University, Baltimore, Maryland, USA.
\end{abstract}

Correspondence: G-J. Tang

Dept of Anesthesiology

Taipei Veterans General Hospital

Taipei

Taiwan

Republic of China

Keywords: Dog

peripheral airway resistance

submucosal oedema

volume loading

Received: May 241993

Accepted after revision October 111993

This work was partially supported by NHLBI R29 HL39406, SCOR HL37119 and NSC 83-0412-B-075-014.
Pulmonary congestion, resulting from either poor left ventricular function [1-3] or rapid volume loading [4], will impair pulmonary function. Increases in airway resistance both in human and animal studies are reported to be more prominent in small rather than large airways [2-6]. The mechanism for this effect remains an issue of debate [7]. The fact that airway obstruction can be abolished by vagotomy or atropine suggests that this response is mediated by a vagal reflex [8-10]. Alternatively, vascular congestion and engorgement may increase peripheral airway resistance (Rp) by altering airway geometry $[1,5]$. It is possible that interstitial oedema could increase Rp via airway compression [11], although it is unlikely to compress airways from the serosal side [12]. However, fluid extravasation from the bronchial circulation may produce intra-airway oedema and increase $\mathrm{Rp}$ [13-15].

In this study, we characterize the effect of increasing intravascular volume on $\mathrm{Rp}$. To test the hypothesis that oedema formation increases $\mathrm{Rp}$, we volume loaded the vascular system with either normal saline (NS) or dex- tran 70 (D70), a polysaccharide with a molecular weight of 70,000 which is hyperoncotic to plasma [16]. Hyperpnoeainduced bronchovascular hyperpermeability was recently reported in guinea-pigs [17], ferrets [18] and dogs [19]. Thus, we used dry air hyperpnoea to increase bronchovascular leakage in canine peripheral airways just prior to increasing intravascular volume with either NS or D70. We also used phenylephrine and nitroglycerine to alter vasomotor tone, in an attempt to determine whether vascular engorgement influenced Rp. Finally, we used atropine to test whether a vagal reflex was responsible for volume loading-induced increases in Rp.

\section{Methods}

Male mongrel dogs (weight (mean \pm SEM) $18.4 \pm 1.2 \mathrm{~kg}$, range $16-21 \mathrm{~kg} ; \mathrm{n}=6$ ) were initially anaesthetized with sodium thiopental $\left(25 \mathrm{mg} \cdot \mathrm{kg}^{-1}\right)$. Anaesthesia was supplemented with a continuous infusion of that drug (1.25 $\left.\mathrm{mg} \cdot \mathrm{min}^{-1}\right)$ and a $25 \mu \mathrm{g}$ injection of fentanyl every $15 \mathrm{~min}$. 
Dogs were intubated and ventilated with a Harvard constant volume respirator (Harvard Apparatus Co., Millis, MA, USA). End-expiratory $\mathrm{CO}_{2}$ was constantly monitored with a $\mathrm{CO}_{2}$ analyser (Beckman LB-2; Beckman Instruments, Fullerton, CA, USA) and maintained between $4-5 \%$ by adjusting respirator frequency. Body temperature was maintained with a warming pad throughout the experiment. Heart rate (HR) and systemic blood pressure (BP) were monitored using a noninvasive blood pressure and heart rate monitor (Datascope Accutorr 1A; Datascope Corp., Paramus, NJ, USA). A Swan Ganz catheter was inserted through the femoral vein and pulmonary arterial pressure (PAP) and central venous pressure (CVP) were continuously monitored on a polygraph (Model 7E polygraph, Grass Instrument Co., Quincy, MA, USA). Pulmonary capillary wedge pressure (PCWP) and cardiac output (CO) were measured every 4 min using thermodilution in conjunction with a cardiac output computer (Model 9520A; American Edward Laboratories, Irvine, CA, USA).

\section{Measurements of peripheral airway resistance}

A fibreoptic bronchoscope (Olympus BF-4B2, $5.5 \mathrm{~mm}$ OD; Olympus Corp. of America, New Hyde Park, NY, USA) was visually guided into either a right or left sublobar segment until the tip obstructed the bronchus. Ventilation through this blocked segment could then occur only through collateral channels [20]. A constant flow $\left(200 \mathrm{ml} \cdot \mathrm{min}^{-1}\right)$ of room temperature $\left(23^{\circ} \mathrm{C}\right) 5 \% \mathrm{CO}_{2}$ in air was delivered to the wedged segment through one lumen of a dual lumen catheter inserted through the suction port of the bronchoscope. Sublobar segment airway pressure (Paw) distal to the tip of the bronchoscope was recorded via the other lumen. Peripheral airway resistance (Rp) under quasi-static conditions was calculated from measurements made at functional residual capacity. With the ventilator stopped, Paw plateaus at a pressure (Palv) above alveolar pressure in the surrounding unobstructed lung. At this time, $\mathrm{Rp}=(\mathrm{Paw}-\mathrm{Palv}) \cdot 200 \mathrm{ml}^{-1} \cdot \mathrm{min}$. $\mathrm{Rp}$ data are presented in $\mathrm{cmH}_{2} \mathrm{O} \cdot \mathrm{ml}^{-1} \cdot \mathrm{s}$. Approximately $90 \%$ of the Rp measured with our wedged bronchoscope technique occurs in respiratory bronchioles and alveolar ducts [20].

\section{Challenge with dry airflow}

Airflow was increased from 200 to $1,500 \mathrm{ml} \cdot \mathrm{min}^{-1}$ for a 2 min period. After $2 \mathrm{~min}$, airflow was returned to the prechallenge flow rate and $\mathrm{Rp}$ was monitored until a stable baseline was re-established.

\section{Experimental Protocols}

Rp during volume loading with either normal saline (NS) or dextran 70 (D70). After establishing stable baselines for Rp, PAP, PCWP, CO and haematocrit, NS was infused at a rate of $\sim 50 \mathrm{ml} \cdot \mathrm{min}^{-1}$ over a 15-20 min period until PCWP increased to $15 \mathrm{mmHg}$. Rp, CO, PAP, BP and
HR were recorded every $4 \mathrm{~min}$. Immediately after the infusion was completed, blood was obtained for measurement of haematocrit. At least two weeks later, the same dogs were used in a similar protocol in which D70 (Pharmacia, UK) was used in place of NS. D70 was infused at a rate of $\sim 25 \mathrm{ml} \cdot \mathrm{min}^{-1}$ over a $15-20$ min period until PCWP in-creased to $15 \mathrm{mmHg}$.

Rp during volume loading with either NS or D70 after dry air challenge. Two bronchoscopes were simultaneously wedged, one in each lung. One randomly selected lung was used for control, and the contralateral lung was exposed for $2 \mathrm{~min}$ to dry airflow $\left(1,500 \mathrm{ml} \cdot \mathrm{min}^{-1}\right)$ 30 min post-challenge. When $\mathrm{Rp}$ on the dry air challenged side had returned to control levels, NS was infused at a rate of $50 \mathrm{ml} \cdot \mathrm{min}^{-1}$ over a $15-20 \mathrm{~min}$ period until PCWP increased to $15 \mathrm{mmHg}$. At least two weeks later, the same dogs were used in a similar protocol with D70 substituted for NS. Rp, CO, PAP, BP and HR were recorded every $4 \mathrm{~min}$.

Rp after vasoconstriction with phenylephrine. Phenylephrine (Sigma, MO, USA) (10 $\mu \mathrm{g} \cdot \mathrm{kg}^{-1} i . v$.) was injected via the femoral vein after recording baseline values for $\mathrm{Rp}, \mathrm{CO}$, PAP, PCWP, BP and HR. Changes in Rp and haemodynamic data were recorded at $30 \mathrm{~s}, 2$ and 6 min after administration of the drug.

Rp after vasodilation with nitroglycerine. Nitroglycerine (American Hospital Supply, UK) $\left(10 \mu \mathrm{g} \cdot \mathrm{kg}^{-1} i . v\right.$. $)$ was injected into the femoral vein after recording baseline values for Rp, CO, PAP, PCWP, BP and HR. Changes in $\mathrm{Rp}$ and haemodynamic data were recorded at $30 \mathrm{~s}$, and at 2 and 6 min after treatment with the drug.

Rp during volume loading and vasoconstriction in lung segments previously challenged with dry airflow. Two bronchoscopes were simultaneously wedged, one in each lung. One sublobar segment served as control, while a contralateral segment was exposed for 2 min to dry airflow $\left(1,500 \mathrm{ml} \cdot \mathrm{min}^{-1}\right)$. After recording baseline values for Rp, CO, PAP, PCWP, BP and HR, phenylephrine $\left(10 \mu \mathrm{g} \cdot \mathrm{kg}^{-1} i . v\right.$.) was injected into the femoral vein and $\mathrm{Rp}$ and haemodynamic data were recorded at $30 \mathrm{~s}, 2 \mathrm{~min}$ and 6 min after drug delivery. The effect of phenylephrine was transient and disappeared within 2 min. When all physiological variables had returned to baseline, NS was infused at a rate of $50 \mathrm{ml} \cdot \mathrm{min}^{-1}$ over a $15-20 \mathrm{~min}$ period until PCWP increased to $15 \mathrm{mmHg}$. Rp, CO, PAP, BP and HR were recorded every $4 \mathrm{~min}$. At the end of infusion, phenylephrine $\left(20 \mu \mathrm{g} \cdot \mathrm{kg}^{-1}\right)$ was injected intravenously, and $\mathrm{Rp}$ and haemodynamic data were recorded at $30 \mathrm{~s}$ and $2 \mathrm{~min}$ after administration of the drug.

$R p$ during volume loading in the presence of muscarinic blockade. Dogs were pretreated with atropine (Sigma, MO, USA) (0.1 mg. $\mathrm{kg}^{-1}$ i.v.). When a stable baseline $\mathrm{Rp}$ had been established, NS was infused at a rate of 50 $\mathrm{ml} \cdot \mathrm{min}^{-1}$ over a $15-20 \mathrm{~min}$ period until PCWP increased to $15 \mathrm{mmHg}$, and $\mathrm{Rp}, \mathrm{CO}, \mathrm{PAP}, \mathrm{BP}$ and $\mathrm{HR}$ were recorded every $4 \mathrm{~min}$. 


\section{Statistical analyses}

Repeated measures analysis of variance (ANOVA) and Duncan's multiple range tests were used to analyse all time course data. Mean data compared before and after treatment were analysed using paired t-tests. Pearson's product-moment correlation coefficient (r) was used to analyse haemodynamic data. Spearman's rank correlation $\left(\mathrm{R}_{\mathrm{s}}\right)$ analysis was used to examine the relationship between dry air- and NS infusion-induced responses in the canine lung periphery. All values represent mean \pm SEM. Statistical significance was judged at $\mathrm{p}<0.05$ in all cases.

\section{Results}

Rp during volume loading with either NS or D70

Infusion of NS produced a stepwise increase in $\mathrm{Rp}$ from $0.69 \pm 0.11$ to $0.93 \pm 0.14 \mathrm{cmH}_{2} \mathrm{O} \cdot \mathrm{ml}^{-1} \cdot \mathrm{s}$ (fig. 1) and was correlated with increasing PCWP $(r=0.78$, $\mathrm{p}<0.01)$ and infusion volume $(\mathrm{r}=0.67, \mathrm{p}<0.01)$. In contrast, $\mathrm{Rp}$ was not significantly $(1.27 \pm 0.22$ to $1.29 \pm 0.24$ $\left.\mathrm{cmH}_{2} \mathrm{O} \cdot \mathrm{ml}^{-1} \cdot \mathrm{s} ; \quad \mathrm{p}>0.05\right)$ affected by infusion of $\mathrm{D} 70$, despite increases in PCWP similar to that seen with NS (fig. 2). During volume loading with NS, Rp was significantly greater than that recorded with D70 at $8(\mathrm{p}<0.05)$, $12(\mathrm{p}<0.01)$ and $16 \mathrm{~min}(\mathrm{p}<0.01)$ during the infusion period (fig. 1). On average, $397 \pm 13 \mathrm{ml}$ of D70 $(\mathrm{n}=6)$ was needed to increase PCWP to $15 \mathrm{mmHg}$, which was significantly $(\mathrm{p}<0.01)$ less than the $808 \pm 39 \mathrm{ml}$ of NS used for the same purpose (fig. 2). CO significantly increased $(\mathrm{p}<0.01)$ after infusion of either NS or D70, and the magnitude of the increase was similar regardless of infusate (fig. 2).

PAP and mean systemic blood pressure (MBP) significantly increased $(\mathrm{p}<0.01)$ after NS and D70 infusion, but the increases were similar regardless of infusate (table

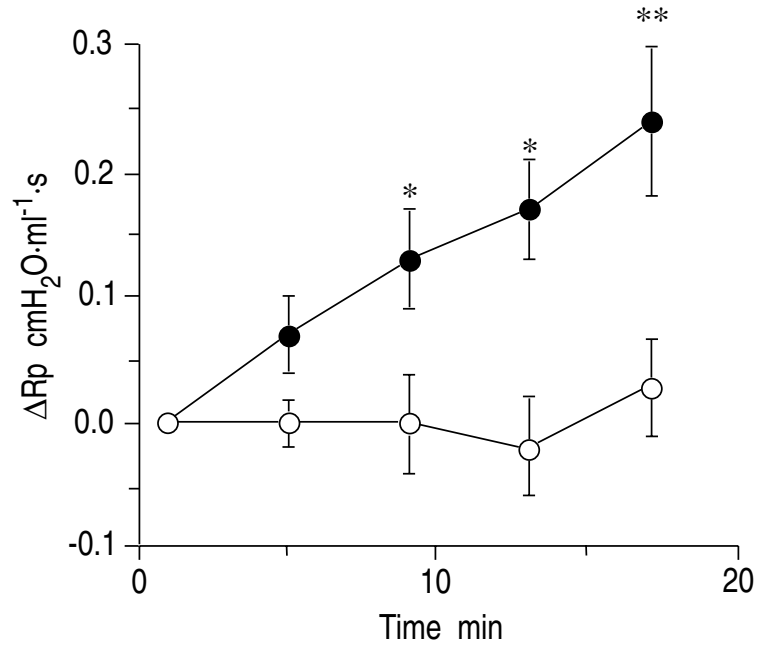

Fig. 1. - Change in peripheral airway resistance $(\Delta \mathrm{Rp})$ during continuous infusion of either normal saline or dextran 70 . *: 0.05 ; and **: 0.01 level of significance comparing normal saline to dextran 70 . Values represent mean $\pm \operatorname{SE}(n=6)$. - — : normal saline; - $-\mathrm{O}-$ : dex$\operatorname{tran} 70$.
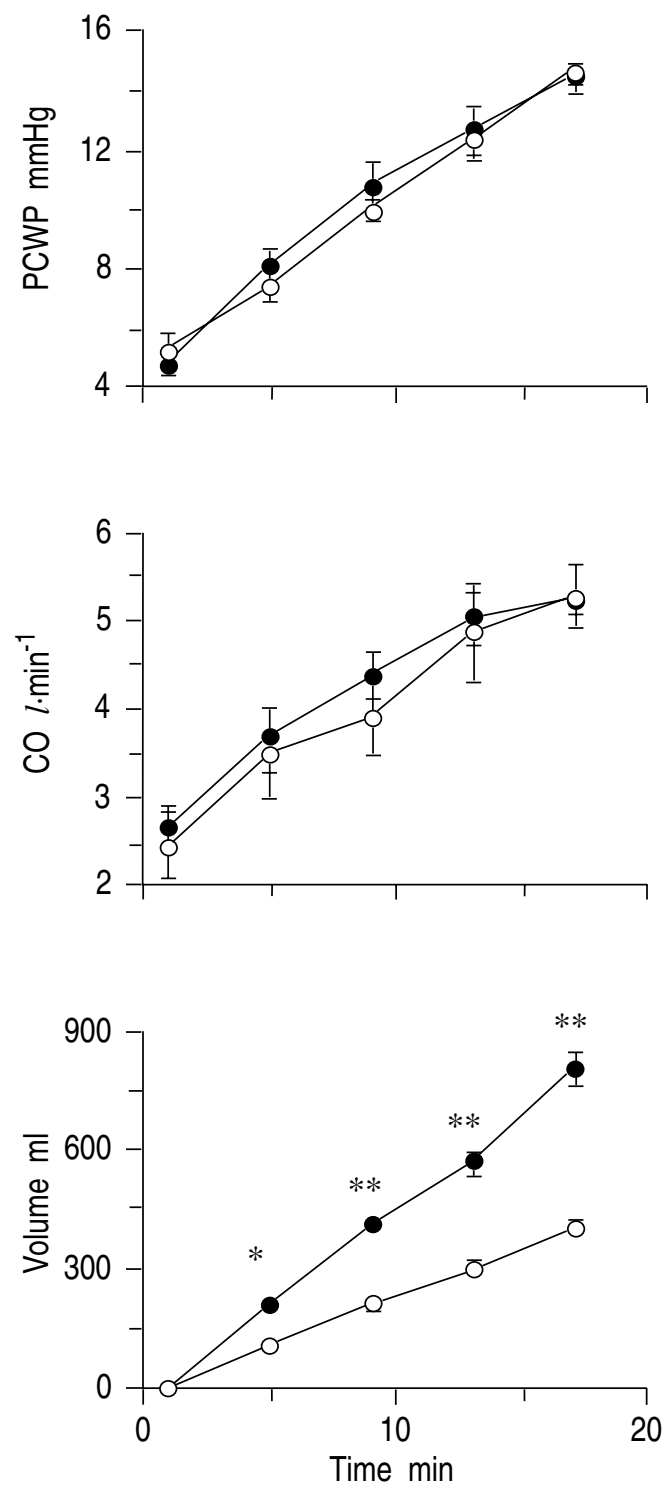

Fig. 2. - Pulmonary capillary wedge pressure (PCWP), cardiac output $(\mathrm{CO})$ and volume of infusate during continuous infusion of either normal saline or dextran 70. *: 0.05 ; and **: 0.01 level of significance comparing normal saline to dextran $70(n=6)$. - - - : normal saline; -O-: dextran 70 .

1). Volume loading with either solution did not significantly alter HR (table 1). After infusion of NS and D70, haematocrit decreased $(\mathrm{p}<0.01)$ from $39 \pm 0.6$ to $28 \pm 0.4 \%$ and from $39 \pm 0.9$ to $29 \pm 1.0 \%$, respectively. There was no significant difference $(\mathrm{p}=0.68)$ in the effect of NS and D70 on haematocrit.

Rp during volume loading with either NS or D70 after dry air challenge.

On average, $\mathrm{Rp}$ increased from $1.08 \pm 0.18$ to $1.88 \pm 0.31$ $\mathrm{cmH}_{2} \mathrm{O} \cdot \mathrm{ml}^{-1} \cdot \mathrm{s} 2 \mathrm{~min}$ after dry air challenge; representing an $84 \pm 34 \%$ increase above the original baseline $(n=6$; $\mathrm{p}<0.01)$.

The increase in Rp during infusion of NS was significantly greater $(\mathrm{p}<0.01)$ in sublobar segments previously challenged with dry airflow than contralateral control 
Table 1. - Haemodynamic changes before and after infusion of either normal saline or dextran 70

\begin{tabular}{llcccc}
\hline & & \multicolumn{2}{c}{ Normal saline } & \multicolumn{2}{c}{ Dextran 70} \\
& & Before & After & Before & After \\
\hline PCWP & $\mathrm{mmHg}$ & $4.8 \pm 0.3$ & $14.5 \pm 0.5^{* *}$ & $5.3 \pm 0.6$ & $14.7 \pm 0.3^{* *}$ \\
PAP & $\mathrm{mmHg}$ & $14.9 \pm 0.86$ & $21.4 \pm 0.93^{* *}$ & $12.8 \pm 0.84$ & $21.6 \pm 0.63^{* *}$ \\
$\mathrm{CO}$ & $l \cdot \mathrm{min}^{-1}$ & $2.67 \pm 0.15$ & $5.23 \pm 0.13^{* *}$ & $2.47 \pm 0.41$ & $5.27 \pm 0.36^{* *}$ \\
MBP & $\mathrm{mmHg}$ & $83.6 \pm 9.05$ & $112 \pm 7.27^{*}$ & $78.0 \pm 4.26$ & $105 \pm 10.1^{*}$ \\
HR & beats·min & $90.4 \pm 6.15$ & $104.5 \pm 9.05$ & $90.2 \pm 8.00$ & $98.5 \pm 8.00$ \\
CVP & mmHg & $5.67 \pm 0.49$ & $13.8 \pm 0.48^{* *}$ & $5.33 \pm 0.42$ & $12.8 \pm 0.60^{* *}$
\end{tabular}

Data are presented as mean士SEM. PCWP: pulmonary artery wedge pressure; PAP: pulmonary artery pressure; CO: cardiac output; MBP: mean systemic blood pressure; HR: heart rate; CVP: central venous pressure. *: 0.05; and **: 0.01 level of significance comparing before and after fluid infusion.

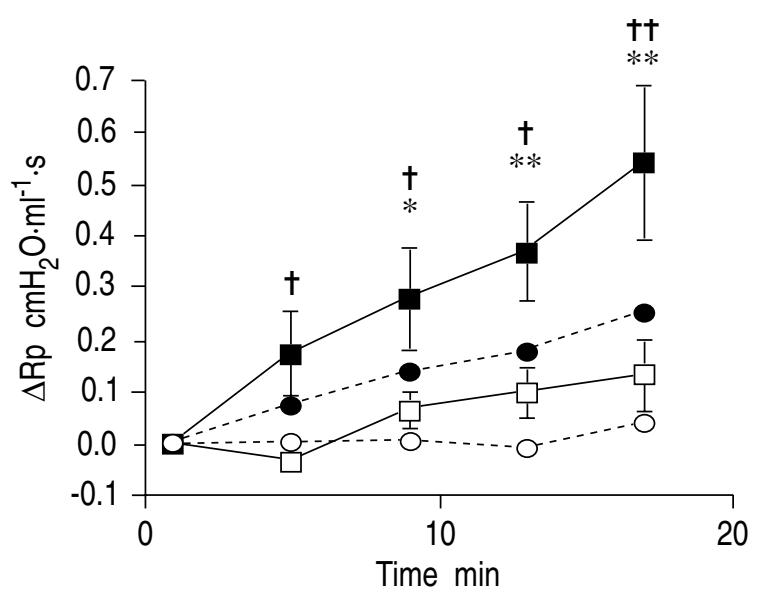

Fig. 3. - Changes in peripheral airway resistance (Rp) during infusion of either normal saline (NS) or dextran 70 (D70) in unexposed control and contralateral sublobar segments previously exposed to dry air $\left(1,500 \mathrm{ml} \cdot \mathrm{min}^{-1}\right)$. Data for NS and D70 are reproduced from figure 1. *: 0.05; and **: level of significance comparing dry air + NS to NS. ${ }^{+},{ }^{+t} ; 0.05$ and 0.01 . level of significance comparing dry air + NS to dry air + D70 (n=6). — - - : dry air + NS; — - - : dry air + D70; - -०- -: NS; - -O- -: D70.

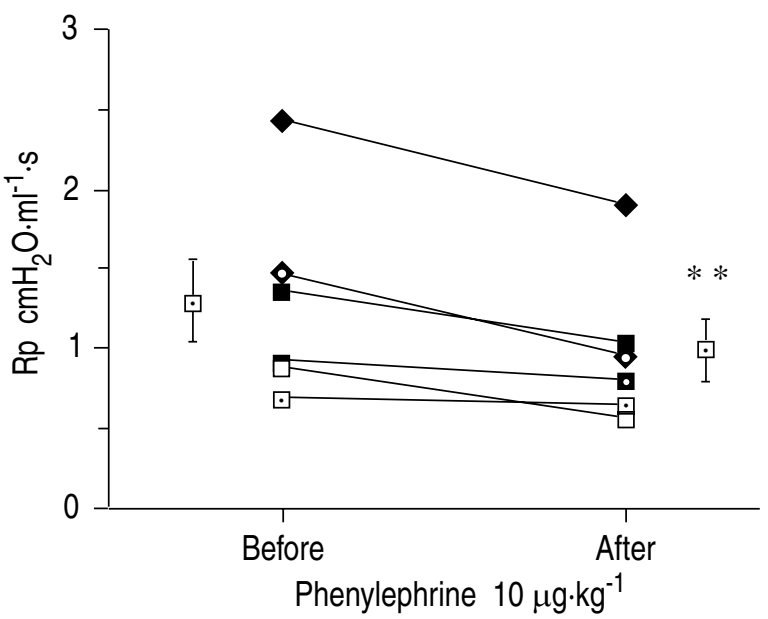

Fig. 4. - Baseline peripheral airway resistance (Rp) before and after phenylephrine $\left(10 \mu \mathrm{g} \cdot \mathrm{kg}^{-1}\right.$ i.v. $)$. Mean \pm SEM and individual values are depicted $(\mathrm{n}=6)$. $* *: \mathrm{p}<0.01$.

segments that were not exposed to dry air (fig. 3). After dry air challenge, $\Delta \mathrm{Rp}$ during infusion of NS $(1.33 \pm 0.2$ to $\left.1.86 \pm 0.29 \mathrm{cmH}_{2} \mathrm{O} \cdot \mathrm{ml}^{-1} \cdot \mathrm{s}\right)$ was significantly greater $(\mathrm{p}<0.01)$ than the $\Delta \mathrm{Rp}$ during infusion of D70 $(1.38 \pm 0.48$ to $1.54 \pm 0.53 \mathrm{cmH}_{2} \mathrm{O} \cdot \mathrm{ml}^{-1} \cdot \mathrm{s}$ ) in the same animals (fig. 3). In the $\mathrm{D} 70$ experimental series, $\mathrm{Rp}$ increased from $1.07 \pm 0.26$ to $1.89 \pm 0.63 \mathrm{cmH}_{2} \mathrm{O} \cdot \mathrm{ml}^{-1} \cdot \mathrm{s} 2 \mathrm{~min}$ after the dry air challenge $(n=6 ; p<0.01)$. An average of $26 \pm 1.8 \mathrm{~min}$ $(n=12)$ separated the end of the dry air challenge from the beginning of volume infusion. Spearman's rank analysis revealed a significant correlation $\left(\mathrm{r}_{\mathrm{s}}=0.77, \mathrm{p}=0.038\right.$; $\mathrm{n}=6$ ) between the peak response to dry air challenge $\left(\Delta \mathrm{Rp}=0.90 \pm 0.25 \mathrm{cmH}_{2} \mathrm{O} \cdot \mathrm{ml}^{-1} \cdot \mathrm{s}\right)$ before volume loading with NS and the maximum change in $\mathrm{Rp}$ at the end of infusion with $\mathrm{NS}\left(\Delta \mathrm{Rp}=0.53 \pm 0.15 \mathrm{cmH}_{2} \mathrm{O} \cdot \mathrm{ml}^{-1} \cdot \mathrm{s}\right)$.

\section{Rp after vasoconstriction with phenylephrine.}

Phenylephrine $\left(10 \mu \mathrm{g} \cdot \mathrm{kg}^{-1}\right)$ significantly decreased $(\mathrm{p}<0.01)$ baseline $\mathrm{Rp}$ (fig. 4), HR ( $<<0.01), \mathrm{CO}(\mathrm{p}<0.05)$, and increased PCWP $(\mathrm{p}<0.01)$, CVP $(\mathrm{p}<0.01)$, PAP $(\mathrm{p}<0.01)$ and MAP $(\mathrm{p}<0.01)($ table 2$)$.

\section{Rp after vasodilation with nitroglycerine.}

Although nitroglycerine $\left(10 \mu \mathrm{g} \cdot \mathrm{kg}^{-1}\right)$ significantly decreased PCWP $(\mathrm{p}<0.01)$, CVP $(\mathrm{p}<0.05)$, PAP $(\mathrm{p}<0.01)$ and MAP $(\mathrm{p}<0.05)$, and significantly increased HR $(\mathrm{p}<0.01)$ and $\mathrm{CO}(\mathrm{p}<0.05)$, it did not affect $\mathrm{Rp}(\mathrm{p}=0.50)$ (fig. 5, table 2).

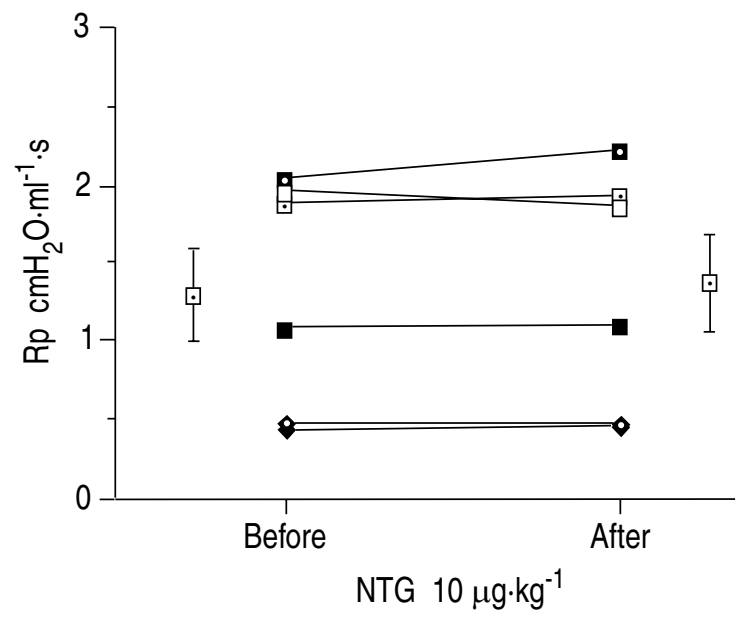

Fig. 5. - Baseline peripheral airway resistance (Rp) before and after nitroglycerine $\left(10 \mu \mathrm{g} \cdot \mathrm{kg}^{-1}\right.$ i.v. $)$. Mean \pm SEM and individual values are depicted $(n=6)$. NTG: nitroglycerine. 
Table 2. - Haemodynamic changes before and after either nitroglycerine $\left(10 \mu \mathrm{g} \cdot \mathrm{kg}^{-1} \mathrm{i} . v\right.$.) or phenylephrine $\left(10 \mu \mathrm{g} \cdot \mathrm{kg}^{-1}\right.$ i.v. $)$

\begin{tabular}{|c|c|c|c|c|c|}
\hline & \multicolumn{2}{|c|}{ Nitroglycerine } & \multicolumn{2}{|c|}{ Phenylephrine } \\
\hline & & Before & After & Before & After \\
\hline PCWP & $\mathrm{mmHg}$ & $6.67 \pm 0.21$ & $4.43 \pm 0.21 * *$ & $6.17 \pm 0.31$ & $13.8 \pm 0.79 * *$ \\
\hline PAP & $\mathrm{mmHg}$ & $17.0 \pm 0.58$ & $14.0 \pm 0.71 * *$ & $17.0 \pm 1.41$ & $34.3 \pm 0.48^{* *}$ \\
\hline $\mathrm{CO}$ & $l \cdot \min ^{-1}$ & $3.12 \pm 0.03$ & $4.53 \pm 0.32 *$ & $3.15 \pm 0.1$ & $1.80 \pm 0.14^{* *}$ \\
\hline MBP & $\mathrm{mmHg}$ & $102 \pm 8.3$ & $90.5 \pm 7.38 *$ & $83.0 \pm 4.52$ & $115 \pm 3.61 * *$ \\
\hline & beats. $\min ^{-1}$ & $69.3 \pm 3.3$ & $96.9 \pm 6.72 * *$ & $63.5 \pm 6.13$ & $38.8 \pm 3.22 * *$ \\
\hline CVP & $\mathrm{mmHg}$ & $5.25 \pm 0.97$ & $4.23 \pm 0.68 *$ & $5.10 \pm 0.77$ & $12.7 \pm 0.82 * *$ \\
\hline
\end{tabular}

Data are presented as mean \pm sem. *: 0.05 ; and **: 0.01 level of significance comparing before and after drug inter-

vention. For abbreviations see legend to table 1 .

Rp during volume loading and vasoconstriction in lung segments previously challenged with dry airflow

Phenylephrine significantly decreased Rp in control segments before (fig. 6 : points $1-2,1.25 \pm 0.31$ to $0.99 \pm 0.23$ $\mathrm{cmH}_{2} \mathrm{O} \cdot \mathrm{ml}^{-1} \cdot \mathrm{s} ; \mathrm{p}<0.01$ ) and after (fig. 6: points 3-4, $1.43 \pm 0.37$ to $\left.1.24 \pm 0.32 \mathrm{cmH}_{2} \mathrm{O} \cdot \mathrm{ml}^{-1} \cdot \mathrm{s} ; \mathrm{p}<0.05\right)$ volume loading with normal saline. Volume loading significantly increased Rp (fig 6: points $2-3,0.99 \pm 0.23$ to $1.43 \pm 0.37$ $\left.\mathrm{cmH}_{2} \mathrm{O} \cdot \mathrm{ml}^{-1} \cdot \mathrm{s} ; \mathrm{p}<0.05\right)$. After volume loading, although treatment with phenylephrine decreased Rp (1.43 \pm 0.37 to $\left.1.24 \pm 0.31 \mathrm{cmH}_{2} \mathrm{O} \cdot \mathrm{ml}^{-1} \cdot \mathrm{s} ; \mathrm{p}<0.05\right)$, $\mathrm{Rp}$ remained significantly elevated when compared to the preinfusion value (fig. 6: 4 vs 2; $<<0.01$ ).

In the contralateral lung, dry air challenge increased $\mathrm{Rp}$ on average from $0.69 \pm 0.23$ to $1.20 \pm 0.38 \mathrm{~cm} \mathrm{H}_{2} \mathrm{O} \cdot \mathrm{ml}^{-1} \cdot \mathrm{s}$ 2 min after dry air challenge; representing an $83 \pm 20 \%$ increase above the original baseline $(n=6, p<0.01)$. Treatment with phenylephrine tended to decrease $\mathrm{Rp}$ in contralateral lung segments that were previously chal-

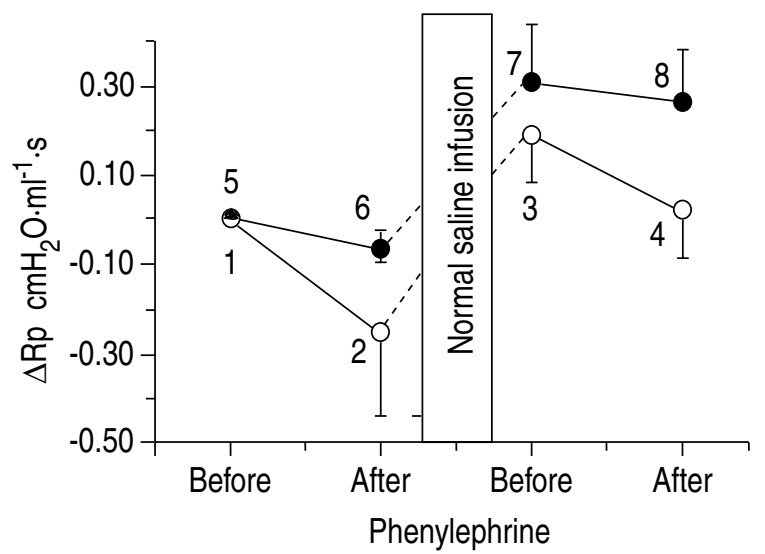

Fig. 6. - Change in peripheral airway resistance $(\Delta R \mathrm{R})$ during volume loading and vasoconstriction in control lung segments and contralateral lung segments previously challenged with dry airflow. Open symbols represent $\mathrm{Rp}$ before and after phenylephrine $\left(10 \mu \mathrm{g} \cdot \mathrm{kg}^{-1}\right.$; points 1 vs $2 ; \mathrm{p}<0.01$ ), after infusion of normal saline (points 2 vs $3 ; \mathrm{p}<0.01$ ), and after a second treatment with phenylephrine $\left(20 \mu \mathrm{g} \cdot \mathrm{kg}^{-1}\right.$; points 3 vs $4 ; \mathrm{p}<0.01)$ in control sublobar segments $(\mathrm{n}=5)$. Closed symbols represent $\mathrm{Rp}$ before and after phenylephrine $\left(10 \mu \mathrm{g} \cdot \mathrm{kg}^{-1}\right.$; points $5 \mathrm{vs}$ 6; $\mathrm{p}>0.05$ ), after infusion of normal saline (points 6 vs 7 ; $\mathrm{p}<0.01$ ), and after a second treatment with phenylephrine $\left(20 \mu \mathrm{g} \cdot \mathrm{kg}^{-1}\right.$; points 7 vs 8 ; p $>0.05)$ in sublobar segments previously challenged with dry air $\left(1,500 \mathrm{ml} \cdot \mathrm{min}^{-1} ; \mathrm{n}=5\right)$. In addition, points 2 vs $4 ; \mathrm{p}<0.01$; points 6 vs $8 ; \mathrm{p}<0.01 ;$ points 4 vs $8 ; \mathrm{p}<0.01(\mathrm{n}=5)$. - air; —O-: control.

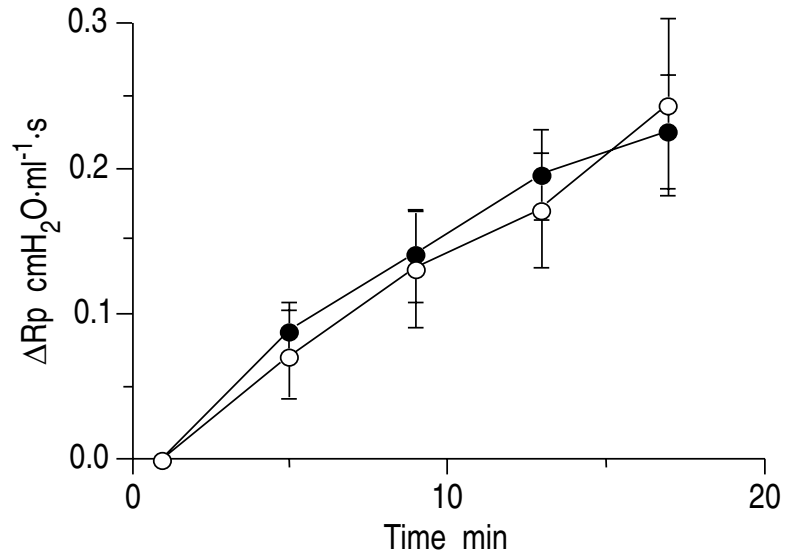

Fig. 7. - Change in peripheral airway resistance $(\Delta R p)$ during continuous infusion of normal saline before and after atropine $(0.1$ $\mathrm{mg} \cdot \mathrm{kg}^{-1}$ i.v. $)$ treatment $(\mathrm{n}=5)$. ——: atropine; —- -

lenged with dry air (fig. 6: $5-6,1.38 \pm 0.35$ to $1.26 \pm 0.29$ $\left.\mathrm{cmH}_{2} \mathrm{O} \cdot \mathrm{ml}^{-1} \cdot \mathrm{s} ; \mathrm{p}<0.05\right)$, and volume loading significantly increased $\mathrm{Rp}$ in these segments (fig. 6: 6-7, 1.26 \pm 0.29 to $\left.1.68 \pm 0.42 \mathrm{cmH}_{2} \mathrm{O} \cdot \mathrm{ml}^{-1} \cdot \mathrm{s} ; \quad \mathrm{p}<0.01\right)$. After volume loading, although treatment with phenylephrine tended to decrease Rp (fig. 6: 7-8, $1.68 \pm 0.42$ to $1.62 \pm 0.38$ $\left.\mathrm{cmH}_{2} \mathrm{O} \cdot \mathrm{ml}^{-1} \cdot \mathrm{s} ; \mathrm{p}>0.05\right), \mathrm{Rp}$ was still significantly elevated when compared to the preinfusion level (fig. 6: 6 vs 8, $\mathrm{p}<0.01)$. Furthermore, when compared to control segments, Rp in lung segments previously challenged with dry air was significantly elevated after volume loading and treatment with phenylephrine (fig. 6: 4 vs 8; $<<0.01$ ).

$R p$ during volume loading in the presence of muscarinic blockade. $\mathrm{Rp}$ increased significantly $(1.05 \pm 0.32$ to $\left.1.28 \pm 0.36 \mathrm{cmH}_{2} \mathrm{O} \cdot \mathrm{ml}^{-1} \cdot \mathrm{s} ; \mathrm{p}<0.01\right)$ after NS infusion, even in the presence of muscarinic blockade (fig. 7). The increase in $\mathrm{Rp}$ before and after administration of $i . v$. atropine did not differ significantly $(\mathrm{p}=0.90)$ at any point in time.

\section{Discussion}

In our model, $\mathrm{Rp}$ reflects the resistance of peripheral airways that connect at the level of the respiratory bronchiole or alveolar duct, and provide collateral ventilation between adjacent sublobar regions of the canine lung [20]. Volume loading with NS increases PCWP (i.e. 
produces pulmonary congestion) and increases peripheral airway resistance in canine lungs (figs 1 and 2). These results are similar to those reported previously by other investigators using different techniques to study canine peripheral airways. HogG et al. [5] demonstrated that increased left atrial pressure (LAP) reversibly increased $\mathrm{Rp}$ in dogs, and suggested that this increase was due to a vascular effect. IsHII et al. [6] reported a biphasic increase in canine $\mathrm{Rp}$ after increasing LAP, and suggested that the initial phase resulted from a vagal reflex. They speculated that the second phase was due to either peribronchial or airway oedema formation. Finally, Rolla et al. [4] rapidly infused NS into human volunteers and found that small airway resistance increased. They suggested that pulmonary interstitial oedema developed during volume loading.

Fluid movement between intravascular and interstitial spaces of the lung should follow Starling's equation [21], and infusion of NS should facilitate vascular leakage. In contrast, infusion of $6 \%$ dextran 70 to produce a similar degree of pulmonary congestion (i.e. the same level of PCWP as that seen with NS) should reduce vascular leakage. We have demonstrated that in contrast to NS, infusion of D70 does not increase Rp even though the PCWP, CVP and CO is similar to that recorded during NS infusion (figs 1 and 2 and table 1). Thus, D70 and NS infusions should produce a similar degree of vascular engorgement. The fact that these two infusates differentially alter Rp indicates that vascular engorgement does not affect Rp, and suggests that formation of oedema increases Rp after NS infusion.

The volume needed to increase PCWP during infusion with NS was significantly greater than that needed with D70 (fig. 2). Several studies [22, 23] have demonstrated that fluid resuscitation during shock requires less D70 when compared to NS to produce the same LAP. Furthermore, pulmonary function was better and the accumulation of lung water was less when D70 was compared to crystalloid infusate [22]. These results are consistent with the present study, and suggest that deterioration of pulmonary function during crystalloid resuscitation is associated with oedema formation.

MiCHEL et al. [12] demonstrated morphometrically that interstitial pulmonary oedema via the pulmonary circulation did not compress small airways. However, pulmonary congestion could increase capillary hydrostatic pressure via the bronchial circulation [24], increase fluid exudation, and cause airway submucosal oedema [25, 26]. Fluid extravasation from the bronchial circulation could then increase $\mathrm{Rp}$ in our canine model [13, 14]. Thus, if the increase in Rp after volume loading was due to submucosal oedema, Rp should increase more after exposure to an agent known to increase bronchovascular permeability. Many agents, such as histamine, bradykinin, substance P [27], platelet-activating factor [28] and dry air [17-19], can increase bronchovascular permeability. Twenty five min after exposing the peripheral airways to dry air, we found that Rp was significantly greater after a 20 min NS infusion than when compared to unexposed control segments (fig. 3). We also found that the magnitude of dry airflow-induced bronchoconstriction
(AIB) was significantly correlated with NS infusioninduced increases in Rp. These observations are consistent with the hypothesis that submucosal oedema formation is responsible for infusion-induced increases in Rp. However, we cannot rule out the possibility that oedema formation at the level of the alveolar duct, in addition to submucosal oedema, contributes to volume loading-induced increases in Rp.

Pulmonary congestion and its associated vascular engorgement may increase airway wall thickness and airway resistance. Онснім et al. [29] found a good correlation between submucosal bronchial vessel dilation and PCWP in patients with chronic pulmonary venous hypertension, and CABANES et al. [1] demonstrated that inhalation of an $\alpha$-agonist (methoxamine) reversed bronchial hyperresponsiveness in patients with poor left ventricular function. CSETE et al. [30] showed that vasodilation with nitroglycerine increased $\mathrm{Rp}$ in ewes and was partially reversed by vasoconstriction with vasopressin. LAITINEN et al. [31] reported that a wide variety of drugs decreased canine vascular resistance and increased tracheal mucosal thickness. They also showed that phenylephrine increased vascular resistance and decreased mucosal thickness. In our experimental model, a single intravenous injection of phenylephrine significantly decreased baseline Rp by $25 \%$ (fig. 4). In contrast, despite significant haemodynamic effects reflecting vasodilation (table 2), intravenous nitroglycerine did not significantly increase baseline Rp (fig. 5). The fact that vasodilation did not alter $\mathrm{Rp}$ is consistent with our hypothesis that vascular engorgement is not a major factor in this model.

If the increase in Rp after NS infusion was purely due to vascular engorgement, then phenylephrine should reverse the infusion-induced increase in Rp. Our results demonstrate that after fluid infusion, even after administering a double dose of phenylephrine to compensate for the added volume of distribution of the drug, Rp remained significantly higher than the preinfusion level after phenylephrine (fig. 6: points 2 vs 4). We hypothesize that this phenylephrine-resistant elevation in $\mathrm{Rp}$ is due to submucosal oedema formation in the peripheral airways. Consistent with this hypothesis is the fact that $\mathrm{Rp}$ remained significantly higher in the dry air challenged segments (with presumably increased bronchovascular permeability), when compared to contralateral control segments, after reversing the vascular distention with phenylephrine (fig 6: 4 vs 8).

Several studies have suggested that airway narrowing during pulmonary congestion was vagally-mediated, because airway obstruction during pulmonary congestion was abolished with either atropine or vagotomy [8-10]. However, pretreatment with a dose of atropine that totally blocks muscarinic receptor activity [32] does not affect the increase in canine Rp associated with volume loading in our model. This difference may be due to either: 1) differences between canine trachea and peripheral airway [10]; 2) differences in the time of treatment (we pretreated with atropine whereas the other investigators used this drug to reverse pulmonary congestion $[8,9])$; or 3) differences in protocols, e.g. IsHII et al. [6] abruptly increased left atrial pressure by inflating a 
balloon to $30 \mathrm{mmHg}$, whereas we gradually increased PCWP to $15 \mathrm{mmHg}$ with a $20 \mathrm{~min}$ infusion of normal saline.

In summary, NS infusion causes pulmonary vascular congestion and a concomitant increase in peripheral airway resistance. In contrast to NS, infusion of D70 produces similar degrees of pulmonary congestion but does not increase $\mathrm{Rp}$. When sublobar segments are challenged with dry air in an attempt to alter bronchovascular permeability, $\Delta \mathrm{Rp}$ is increased during NS infusion when compared to control segments. Phenylephrine decreases $\mathrm{Rp}$ after fluid infusion, but does not completely reverse the effect of volume loading on $\mathrm{Rp}$. In addition, $\Delta \mathrm{Rp}$ during fluid infusion is not altered by muscarinic receptor blockade.

We conclude that vascular engorgement does not increase Rp during NS infusion; and that submucosal oedema is the most likely mechanism responsible for normal saline infusion-induced increases in Rp.

Acknowlegements: The author wishes to thank C.E. Stream for his superior technical assistance. W. Mitzner critically reviewed an early draft of this manuscript. The statistical counselling provided by A.W. Kimball Jr, (Johns Hopkins University) is gratefully acknowledged.

\section{References}

1. Cabanes LR, Webber SN, Matran R, et al. Bronchial hyperresponsiveness to methacholine in patients with impaired left ventricular function. N Engl J Med 1989; 320: 1317-1322.

2. Hales C, Kazemi H. Small airway function in myocardial infarction. N Engl J Med 1974; 290: 761-765.

3. Petermann W, Barth J, Entzian P. Heart failure and airway obstruction. Int J Cardiol 1987; 17: 207-209.

4. Rolla G, Bucca C, Polizzi S, et al. Site of airway obstruction after rapid saline infusion in healthy subjects. Respiration 1983; 44: 90-96.

5. Hogg JC, Agarawal JB, Gardiner JS, Palmer WH, Macklem PT. Distribution of airway resistance with developing pulmonary edema in dogs. J Appl Physiol 1972; 32(1): 20-24.

6. Ishii M, Matsuoto N, Fuyuki T, et al. Effects of hemodynamic edema formation on peripheral vs central airway mechanics. J Appl Physiol 1985; 59(5): 1578-1584.

7. Snashall PD, Chung KF. Airway obstruction and bronchial hyperresponsiveness in left ventricular failure and mitral stenosis. Am Rev Respir Dis 1991; 144: 945-956.

8. Chung KF, Keyes SJ, Morgan BM, Jones PW, Snashall PD. Mechanisms of airway narrowing in acute pulmonary edema in dogs: influence of the vagus and lung volume. Clin Sci 1983; 65: 289-296.

9. Jones JG, Lemen R, Graf PD. Changes in airway calibre following pulmonary venous congestion. Br J Anaesth 1978; 50: 743-751.

10. Kappagoda CT, Man GCW, Ravi K, Teo KK. Reflex tracheal contraction during pulmonary venous congestion in the dog. J Phys 1988; 402: 335-346.

11. Milic-Emili J, Ruff F. Effects of pulmonary congestion and edema on the small airways. Bull Eur Physiopathol Respir 1971; 7: 1181-1196.

12. Michel RP, Zocchi L, Rossi A, et al. Does interstitial lung edema compress airways and arteries? A morphometric study. J Appl Physiol 1987; 62(1): 108-115.
13. Hogg JC, Paré PD, Moreno R. The Effect of submucosal edema on airway resistance. Am Rev Respir Dis 1987; 135: S54-S56.

14. Moreno RH, Hogg JC, Paré PD. Mechanics of airway narrowing. Am Rev Respir Dis 1986; 133: 1171-1180.

15. Persson CGA. Role of plasma exudation in asthmatic airways. Lancet 1986; 8516: 1126-1128.

16. Thorein L. The dextrans: clinical data. Dev Biol Standard 1980; 48: 157-167.

17. Garland A, Ray DW, Doerschuk CM, et al. Role of tachykinins in hyperpnea-induced bronchovascular hyperpermeability in guinea-pigs. $J$ Appl Physiol 1991; 70(1): 27-35.

18. Ray DW, Hernandez C, Eappen S, Leff AR, Solway J. Local mucosal cooling/drying causes local bronchovascular hyperpermeability in ferrets. Am Rev Respir Dis 1989; 139: A233.

19. Freed AN, Omori C, Schofield BH, Mitzner W. The distribution and magnitude of dry air-induced bronchovascular hyperpermeability in canine peripheral airways is airflow-dependent. Am Rev Respir Dis 1993; 147: A858.

20. Mitzner W. Collateral ventilation. In: Crystal RG, West JB, et al., eds. The Lung: Scientific Foundations. New York, Raven Press, 1991; pp. 1053-1063.

21. Starling EH. On the absorption of fluids from the connective tissue spaces. J Physiol 1895; 19: 312-326.

22. Modig J. Comparison of effects of dextran-70 and Ringer's acetate on pulmonary function, hemodynamics, and survival in experimental septic shock. Crit Care Med 1988; 16: 266-271.

23. Shoemaker WC. Comparison of the relative effectiveness of whole blood transfusion and various types of fluid therapy in resuscitation. Crit Care Med 1976; 4: 71-78.

24. Deffebach ME, Charan NB, Lakshminarayan S, Butler J. The bronchial circulation. Am Rev Respir Dis 1987; 135: 463-481.

25. Paré PD, Brooks LA, Baile EM. Effect of systemic venous hypertension on pulmonary function and lung water. J Appl Physiol: Respirat Environ Exercise Physiol 1981; 51: 592-597.

26. Paré PD Godden DJ. Airway Edema. In: Crystal RG, West JB eds. The Lung: Scientific Foundations. New York, Raven Press Ltd, 1991, pp. 987-994.

27. Laitinen LA, Laitinen A, Widdicombe J. Effects of inflammatory and other mediators on airway vascular beds. Am Rev Respir Dis 1987; 135: S67-S70.

28. Evans TW, Chung KF, Rogers DF, Barnes PJ. Effect of platelet-activating factor on airway vascular permeability: possible mechanisms. J Appl Physiol 1987; 63(2): 479-484.

29. Ohchimi M, Tagaki S, Nomura N, Tsunematsu K, Suzuki A. Endobrochial changes in chronic pulmonary venous hypertension. Chest 1988; 94: 1127-1132.

30. Csete ME, Abraham WM, Wanner A. Vasomotion influences airflow in peripheral airways. Am Rev Respir Dis 1990; 141: 1409-1413.

31. Laitinen LA, Robinson NP, Laitinen A, Widdicombe JG. Relationship between tracheal mucosal thickness and vascular resistance in dogs. J Appl Physiol 1986; 61(6): 2186-2193.

32. Tang G-J, Freed AN. The Autonomic nervous system modulates dry air-induced constriction in the canine lung periphery. Am Rev Respir Dis 1992; 145: 1301-1305. 